and they also want the commission to set up a system concerning environmental liability to supplement the existing regulatory framework for plant biotechnology.

The industry gave the directive a cautious welcome, despite its rigour. "It will provide the necessary transparency to restore public confidence in the safety of GM products," says Simon Barber, director of the plant biotechnology unit at EuropaBio, the European Association for Bioindustries. "This is an important step towards the end of the moratorium and it will hopefully enable us eventually to sell our products in Europe."

"We understand the demand from society for greater rigour," says Barber. But he warns that over-regulation of plant biotechnology could hinder innovation and put plant geneticists in Europe at a competitive disadvantage.

The moratorium has held up 14 applications for the commercial cultivation of GM plants, including maize and oilseed rape varieties developed by Aventis Crop Science, Syngenta and Plant Genetic Systems.

The environmental group Greenpeace called the directive "a massive improvement" on existing regulations. But a spokesman for the group said that it would not justify lifting the moratorium.

\title{
Canada's BSE fears 'groundless'
}

\section{David Spurgeon, Montreal}

Brazil and Canada moved quickly this week to patch up a row over a Canadian threat to ban Brazilian beef because of fears of bovine spongiform encephalopathy (BSE).

Canada had announced that it would ban imports of Brazilian beef on scientific grounds. But after a barrage of criticism from both countries, the government indicated that the ban was likely to be lifted as suddenly as it had been imposed.

The threat to ban the beef caused uproar in Brazil, and came under fire in Canada after two scientists in the federal health department said publicly that it had no scientific basis and was motivated by politics rather than health concerns.

The Canadian Food Inspection Agency says that the ban was imposed because Brazil failed to supply adequate documentation on cattle it had recently imported from Europe. But critics say the real reason was a longrunning trade dispute between the two countries over aircraft manufacturing subsidies.

The World Trade Organization has ruled that Brazilian subsidies to Embraer, a direct competitor of Canada's Bombardier in the lucrative market for small passenger-jets, are

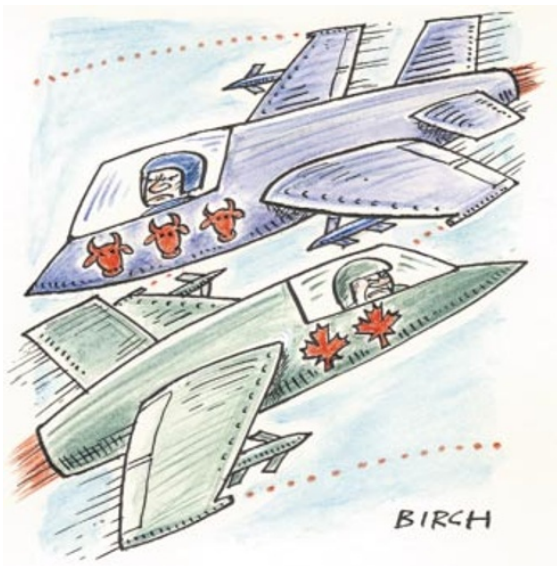

illegal, and that Canada can impose retaliatory trade sanctions. But it has been reluctant to do this, as it regards Brazil as an important regional ally.

In Brazil, where no cases of BSE have been reported, the beef ban was branded a dirty trick in the press.

The mild-mannered Brazilian president, Fernando Henrique Cardoso, warned of a possible trade war with Canada, and the ban sparked public protests and led to Canadian whisky being dumped in the streets of São Paulo.

\section{India promises more earthquake research}

\section{K. S. Jayaraman, New Delhi}

The earthquake that ravaged Gujarat last month has drawn a pledge from the Indian government to increase seismological research and allow participation by foreign scientists.

India has been deeply suspicious of foreign involvement in its earthquake research. Apart from concerns that foreign researchers would use their data to detect Indian nuclear-weapons tests, India had alleged that US researchers abused their access to the Himalayas by attempting to spy on Chinese missile programmes.

And India has previously allowed foreign seismologists to carry out field studies only in collaboration with local scientists. "We don't want to allow outsiders to walk away with data without our people knowing what was collected, and for what purpose," explains Valangiman Ramamurthi, the science secretary.

But after a meeting of India's top scientific administrators, a change of approach was announced last week.

The Himalayas are of great interest to seismologists because they were created by the collision of the Indian and Eurasian tectonic plates, which resulted in the formation

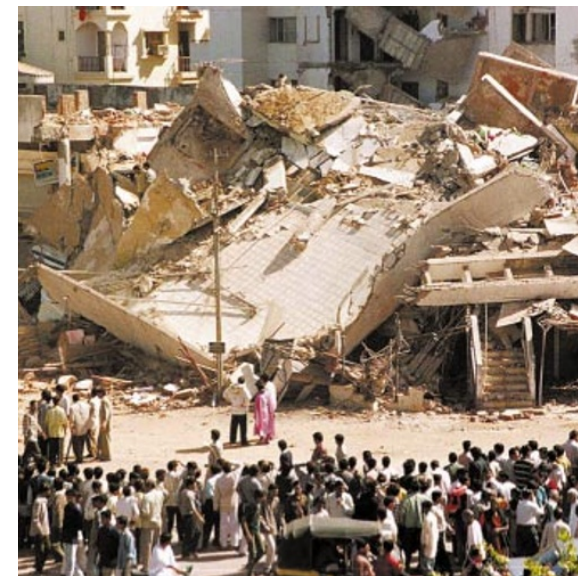

Seismic shock: the Indian government plans to build 40 seismic monitoring stations.

of some two dozen active faults. The Rann of Kutchh, which on 26 January produced the country's worst earthquake in decades, is also of geological interest. But both regions are militarily sensitive.

Access by Western scientists was restricted after an incident in 1974 when it was discovered that a US expedition had left a nuclear-powered sensor on a Himalayan peak so as to spy on Chinese missile launches.

๑ 2001 Macmillan Magazines Ltd
And in 1988, a US gravity survey of the Himalayas was halted after the Indian defence ministry said the data could be used to programme the path of US ballistic missiles flying over the mountain range.

Indian scientists have also been refused access to parts of the Rann of Kutchh including the vast Allah Bund (wall of God) scarp created by an earthquake in 1819 because they lie on the heavily militarized border with Pakistan.

Vinod Gaur, a seismologist with the Centre for Mathematical Modelling and Computer Simulation in Bangalore, welcomed the announcement. "I don't underestimate the security risks near the border, but our attitude should be to encourage important scientific investigations," he says.

Even before the announcement, the Gujarat earthquake seemed to have eased the clampdown on foreign seismologists. Ramamurthi says that more than 30 foreign groups are already studying the aftershocks and other aspects of the earthquake.

The government has also announced a US $\$ 12$ million plan to build 40 seismic monitoring stations in the Himalayas, where it fears the next major earthquake will occur. 